\title{
EFFECTS OF NAA AND DIFFERENT NITROGEN LEVELS ON NUTRIENT UPTAKE BY BARI GOM-26 (TRITICUM AESTIVUM L.)
}

\author{
SAIFUL ISLAM AND NARGIS JAHAN* \\ Plant Physiology Laboratory, Department of Botany, \\ University of Dhaka, Dhaka- 1000. Bangladesh
}

\begin{abstract}
An experiment was conducted to evaluate the effects of NAA $(0,25,50 \mathrm{ppm})$ at varying nitrogen levels $(0,50,75,100 \%$ of the recommended dose) on nitrogen $(\mathrm{N})$, phosphorus (P) and potassium (K) uptake by shoot and root and percentage of total NPK uptake by BARI Gom-26 at flowering and grain filling stage. Application of NAA at varying nitrogen levels had significant effect on P and K uptake by shoot and root at both stages, whereas, the $\mathrm{N}$ content of shoot at flowering stage and of root at the grain filling stage were non-significant.At both the stages, $\mathrm{K}$ content of root increased following all the treatments. At flowering and grain filling stage, $\mathrm{P}$ content of root and shoot increased and decreased due to different treatments. The maximum percentage of total NPK uptake was recorded from $\mathrm{K}$ followed by $\mathrm{N}$ and $\mathrm{P}$ respectively at both stages. In majority cases there was a decreasing trend in percentage uptake of $\mathrm{N}$ and $\mathrm{P}$ at grain filling stage compared with flowering stagewhereas, the trend was almost reverse in case of $\mathrm{K}$. The $\mathrm{N}$ content of grain increased following all the treatments, the maximum being due to 25 ppm NAA in combination with $75 \% \mathrm{~N}$-fertilizer. Only decrease in $\mathrm{P}$ content of grain was recorded when 25 ppm NAA without any N-fertilizer was applied. In case of K content, 50 ppm NAA without any $\mathrm{N}$-fertilizer resulted the only decrease. The highest nitrogen use efficiency (NUE) by total plant was also recorded from 50 ppm NAA in combination with $50 \% \mathrm{~N}$-fertilizer at flowering stage, whereas, from 25 ppm NAA in combination with $75 \% \mathrm{~N}$-fertilizer at grain filling stage.
\end{abstract}

Key words: BARI Gom-26, NAA, Nitrogen levels, Foliar application, Nutrient uptake

\section{Introduction}

Intensive high yield agriculture is largely dependent on addition of fertilizers, especially industrially produced nitrogenous one as it is the major factor limiting yield of crops including wheat(Tilmanet al. 2002 and Andrews et al. 2004). Farmers generally use excess fertilizer for better production. Chemical fertilizers often have low use efficiency and plants cannot uptake all the nutrients beyond its capacity. There must be a balance between nitrogen use efficiency and optimal crop productivity. Currently about 30-50 \% of applied nitrogen fertilizer is taken up by crops and the remainder accumulates in excess in terrestrial and aquatic ecosystems and in the troposphere(Smil 1999 and Cassmanet al. 2002). These excessnitrogen also reduce farmers’ profits, as optimal yields

\footnotetext{
* Corresponding author: Email: <jahan.nargis@yahoo.com>
} 
are not achieved. On the other hand, plants that efficiently absorb and use nutrients greatly enhance the overall efficiency of applied fertilizers, reducing cost of inputs and preventing loss of nutrients to ecosystem (Baligaret al. 2001). As a result, lowering fertilizer input and maximizing nitrogen use efficiency (NUE) needs due attention all over the world. Naphthalene acetic acid (NAA), a synthetic growth regulator at appropriate concentration is known to affect growth, development and other physiological and biochemical processes of cereal crops (Sing and Gill 1985, Jahan and Adam 2011, 2013 and 2014). But,reports regarding the effect of NAA on nutrient content and uptake by cereal crops are meager (Adam et al. 2012). Application of NAA in combination with various nitrogen levels can play important role in reducing production cost of crops as well as balance use for better results both commercially and environmentally. Thus an experiment was carried out to investigate the effects of NAA in combination with varying nitrogen levels on the nutrient content and uptake by BARI GOM-26.

\section{Materials and Methods}

A field experiment was carried out at the Botanical garden of the University of Dhaka during November 2014 to March 2015. Seeds of BARI Gom-26 were collected from BARI (Bangladesh Agricultural Research Institute), Joydebpur, Gazipur. Itis a high yielding, heat tolerant variety recommended for Rabi season and was released in 2010. The experimental soil was analyzed and high levels of phosphorus and low levels of nitrogen and potassium were recorded(Fertilizer Recommendation Guide 2012). Cowdung, TSP, MP and gypsum were applied as basal dose during land preparation. The experiment was laid out in RCBD with five replications. There were three concentrations of NAA viz. $\mathrm{G}_{0}=$ without NAA, $\mathrm{G}_{1}=25 \mathrm{ppm}$ NAA and $\mathrm{G}_{2}=50 \mathrm{ppm}$ NAA, and four levels of $\mathrm{N}$-fertilizer viz. $\mathrm{F}_{0}=$ without any $\mathrm{N}$-fertilizer, $\mathrm{F}_{1}=50 \%$ of the recommended dose, $\mathrm{F}_{2}=$ $75 \%$ of the recommended dose and $\mathrm{F}_{3}=$ full recommended dose of $\mathrm{N}$-fertilizer (urea). As such there were 12 treatment combinations. Two-thirds of the urea was used as basal and the rest one-third was applied at 25 days after sowing. Seeds were sterilized with $0.05 \%$ calcium hypochlorite solution and were sown on November 8, 2014. Plant to plant distance was $10 \mathrm{~cm}$. Thinning was done at the age of 18 days.Weeding was done fortnightly starting from the age of 18 days.Irrigations were also done as per the necessity. Treatments were applied as foliar spray at the age of 30 days. Dry shoot and root were crushed and then used for the determination of Nitrogen $(\mathrm{N})$, phosphorus $(\mathrm{P})$ and potassium $(\mathrm{K})$ content at flowering and grain filling stages whereas, those of grain were determined after harvest. The N, P and $\mathrm{K}$ contents of shoot, root and grain were determined by micro-Kjeldalh's method, vanadate-molybdate yellow color method and flame photometer respectivelyas modified by Huq and Alam (2005). Uptake of NPK of shoot and root and nitrogen use efficiency were calculated using the formula of Nyborget al.(1995). Data were analyzed statistically(Steel et al. 1997) and treatment means were compared by LSD test at $5 \%$ level of significance. 


\section{Results and Discussion}

Results presented in Table 1 show that application of NAA at varying nitrogen levels had significant effect on $\mathrm{P}$ and $\mathrm{K}$ uptake by shoot and root at flowering and grain filling stages. However, $\mathrm{N}$ content of shoot at the flowering stage and root at the grain filling stage were non-significant. The $\mathrm{N}$ content of root at the flowering stage and that of shoot and root at the grain filling stage increased due to all the treatments. The maximum $\mathrm{N}$ content of root at the flowering and grain filling stage was due to $50 \% \mathrm{~N}$-fertilizer (without NAA) and 25 ppm NAA in combination with $75 \% \mathrm{~N}$-fertilizer respectively. Highest $\mathrm{N}$ content of shoot at the flowering and grain filling stage was due to $50 \mathrm{ppm}$ NAA in combination with $50 \%$ N-fertilizer and 25 ppm NAA in combination with $75 \%$ $\mathrm{N}$-fertilizer respectively. At both the stages, $\mathrm{K}$ content of root increased following all the treatments. Maximum $\mathrm{K}$ content of root recorded at the flowering and grain filling stages was due to $75 \%$ N-fertilizer (without NAA) and 25 ppm NAA in combination with $75 \%$ $\mathrm{N}$-fertilizer respectively. Both increase and decrease in $\mathrm{P}$ content of root and shoot at the flowering and grain filling stage were recorded due to different treatments. However, maximum P content of root due to 25 ppm NAA in combination with $75 \%$ N-fertilizer was recorded only in case of root at the flowering stage. The favorable effect of NAA in enhancing the nutrient uptake was reported in cotton (Patel 1992), in fenugreek (Purbey and Sen 2007), in green gram (Rahman and Venkatrama 2006) and in rice (Adam et al. 2012). Increased and decreased uptake of $\mathrm{N}, \mathrm{P}$ and $\mathrm{K}$ due to application of different nitrogen levels in wheat were also reported by Chaturvedi (2006), Kumbharet al. (2007) and Laghariet al. (2010). Thus, the results are in agreement with the findings of previous workers.However, no reports are available on $\mathrm{N}, \mathrm{P}$ and $\mathrm{K}$ uptake by wheat following application of NAA in combination with nitrogen levels.

Findings of this investigation also indicated that the maximum percentage uptake was recorded from $\mathrm{K}$ followed by $\mathrm{N}$ and $\mathrm{P}$ respectively in both the stages (Fig.1). This findings also showed a decreasing tendency in percentage $\mathrm{N}$ and $\mathrm{P}$ uptake in most cases of grain filling stage compared to flowering stage. However, reverse trend was found in case of $\mathrm{K}$ uptake where, percentage uptake of $\mathrm{K}$ was recorded higher in grain filling stage except two treatments $\left(\mathrm{G}_{0} \mathrm{~F}_{3}, \mathrm{G}_{1} \mathrm{~F}_{0}\right)$. At the flowering stage, treatment means varied significantly in case of percentage $\mathrm{P}$ uptake, whereas, at the grain filling stage, significant variations were observed in case of percentage $\mathrm{N}$ uptake. The reason for decreasing percentage uptake of $\mathrm{N}$ and $\mathrm{P}$ at grain filling stage might be due to the transport of $\mathrm{N}$ and $\mathrm{P}$ into developing seed(Chapin and Wardlaw 1988). The consistently increased percentage uptake of $\mathrm{K}$ by BARI Gom-26 up to grain filing stage might be due to the fact that $\mathrm{K}$ maintains water balance and promotes energy generation which is required for moving nutrients in the plant and uptake of other nutrients. Jones et al. (2009) also 
reported that very little of the accumulated $\mathrm{K}$ is used for grain filling in wheat. However, the overall NPK uptake by both shoot and root increased considerably at grain filling stage.

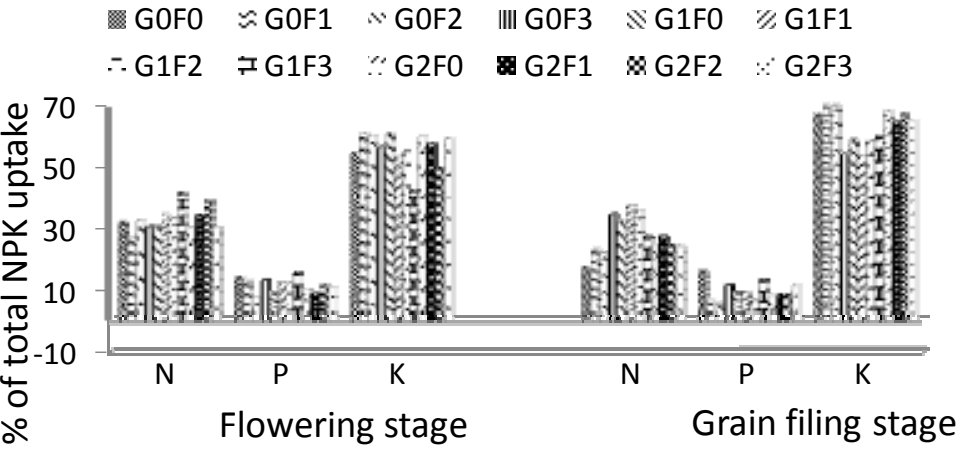

Fig 1. Comparative analysis on percentage of total NPK uptake by BARI Gom-26 at two different stages $\left(\mathrm{LSD}_{0.05}\right.$ for percentage $\mathrm{P}$ of total NPK uptake at flowering stage is 3.97 and percentage $\mathrm{N}$ of total NPK uptake at grain filling stage is 9.38).

With two exceptions the N, P and K contents of grain were found to increase following all the treatments (Table 2). The $\mathrm{N}$ content of grain increased following all the treatments and the maximum was due to 25 ppm NAA in combination with $75 \%$ N-fertilizer (Table 2). Only decrease in $P$ content of grain was due to 25 ppm NAA without any N-fertilizer. Results also showed that K content of grain increased due to all the treatments except 50 ppm NAA without $\mathrm{N}$-fertilizer.None of the value was found significant.Increase in $\mathrm{N}, \mathrm{P}$ and $\mathrm{K}$ contents of grain following NAA application was also reported in different plants viz. rice (Adam et al. 2012), fenugreek (Purbey and Sen 2007) and maize (Akter 2010).

Table 2. Effects of NAA at varying nitrogen levels on NPK contents (\%) of grain of BARI Gom-26 at harvest.

\begin{tabular}{cccc}
\hline Treatments & $\mathrm{N}$ & $\mathrm{P}$ & $\mathrm{K}$ \\
\hline $\mathrm{G}_{0} \mathrm{~F}_{0}$ & 2.091 & 0.286 & 0.094 \\
$\mathrm{G}_{0} \mathrm{~F}_{1}$ & 2.304 & 0.316 & 0.172 \\
$\mathrm{G}_{0} \mathrm{~F}_{2}$ & 2.219 & 0.315 & 0.191 \\
$\mathrm{G}_{0} \mathrm{~F}_{3}$ & 2.404 & 0.315 & 0.250 \\
$\mathrm{G}_{1} \mathrm{~F}_{0}$ & 2.205 & 0.284 & 0.133 \\
$\mathrm{G}_{1} \mathrm{~F}_{1}$ & 2.276 & 0.446 & 0.289 \\
$\mathrm{G}_{1} \mathrm{~F}_{2}$ & 2.432 & 0.506 & 0.270 \\
$\mathrm{G}_{1} \mathrm{~F}_{3}$ & 2.404 & 0.436 & 0.211 \\
$\mathrm{G}_{2} \mathrm{~F}_{0}$ & 2.276 & 0.291 & 0.074 \\
$\mathrm{G}_{2} \mathrm{~F}_{1}$ & 2.233 & 0.504 & 0.270 \\
$\mathrm{G}_{2} \mathrm{~F}_{2}$ & 2.304 & 0.522 & 0.133 \\
$\mathrm{G}_{2} \mathrm{~F}_{3}$ & 2.205 & 0.412 & 0.231 \\
$\mathrm{CV}(\%)$ & 45.19 & 6.67 & 43.97 \\
$\mathrm{LSD}(0.05)$ & $\mathrm{NS}$ & $\mathrm{NS}$ & $\mathrm{NS}$ \\
\hline
\end{tabular}


Nitrogen use efficiency (NUE) was not influenced by any definite treatment in case of shoot and root where, the maximum values were obtained from different treatments in both the stages (Table 3). Significant variations were observed in case of root at flowering stage and shoot at grain filling stage. At the flowering stage, maximum NUE of shoot and that of total plant were recorded from 50 ppm NAA in combination with $50 \%$ $\mathrm{N}$-fertilizer. However, at the grain filling stage, maximum NUE of shoot and that of total plant were recorded from 25 ppm NAA in combination with $75 \% \mathrm{~N}$-fertilizer. This result indicates that lower concentration of NAA with relatively higher dose of N-fertilizer is more efficient in enhancing NUE. This finding is in agreement with the findings of Akinrinde (2006).

Table 3. Effects of NAA at varying nitrogen levels on nitrogen use efficiency (mg N/mg N) of BARI Gom-26 at two different stages.

\begin{tabular}{|c|c|c|c|c|c|c|}
\hline \multirow{2}{*}{ Treatments } & \multicolumn{3}{|c|}{ Flowering } & \multicolumn{3}{|c|}{ Grain filling } \\
\hline & shoot & root & Total plant & shoot & root & Total plant \\
\hline $\mathrm{G}_{0} \mathrm{~F}_{0}$ & - & - & - & - & - & - \\
\hline $\mathrm{G}_{0} \mathrm{~F}_{1}$ & 0.017 & $0.009 \mathrm{a}$ & 0.026 & $0.072 \mathrm{~d}$ & 0.006 & 0.078 \\
\hline $\mathrm{G}_{0} \mathrm{~F}_{2}$ & 0.013 & 0.004 bc & 0.017 & $0.060 \mathrm{~d}$ & 0.002 & 0.062 \\
\hline $\mathrm{G}_{0} \mathrm{~F}_{3}$ & 0.031 & 0.004 bc & 0.035 & $0.062 \mathrm{~d}$ & 0.004 & 0.066 \\
\hline $\mathrm{G}_{1} \mathrm{~F}_{0}$ & - & - & - & - & - & - \\
\hline $\mathrm{G}_{1} \mathrm{~F}_{1}$ & 0.008 & 0.003 bc & 0.011 & $0.158 \mathrm{ab}$ & 0.010 & 0.168 \\
\hline $\mathrm{G}_{1} \mathrm{~F}_{2}$ & 0.033 & $0.006 \mathrm{ab}$ & 0.039 & $0.167 \mathrm{a}$ & 0.008 & 0.175 \\
\hline $\mathrm{G}_{1} \mathrm{~F}_{3}$ & 0.017 & $0.001 \mathrm{c}$ & 0.018 & $0.074 \mathrm{~d}$ & 0.003 & 0.077 \\
\hline $\mathrm{G}_{2} \mathrm{~F}_{0}$ & - & - & - & - & - & - \\
\hline $\mathrm{G}_{2} \mathrm{~F}_{1}$ & 0.102 & $0.006 \mathrm{ab}$ & 0.108 & 0.142 abc & 0.008 & 0.150 \\
\hline $\mathrm{G}_{2} \mathrm{~F}_{2}$ & 0.033 & $0.005 \mathrm{abc}$ & 0.038 & $0.038 \mathrm{~d}$ & 0.005 & 0.043 \\
\hline $\mathrm{G}_{2} \mathrm{~F}_{3}$ & 0.001 & 0.003 bc & 0.004 & $0.049 \mathrm{~d}$ & 0.003 & 0.052 \\
\hline CV(\%) & 23.12 & 72.46 & 19.64 & 59.23 & 88.50 & 59.08 \\
\hline LSD (0.05) & NS & 0.004 & NS & 0.066 & NS & NS \\
\hline
\end{tabular}

*Means in a vertical column followed by same letter do not differ significantly at $5 \%$ level

The higher uptake of N, P and K may have resulted from higher yield and production of higher dry matter. The increased uptake of NPK and NUE due to use of lower doses of $\mathrm{N}$-fertilizer in combination with NAA might be the result of stimulatory effect of NAA in absorbing these nutrients by BARI GOM-26.

\section{References}

Adam, A.M.M.G., N. Jahan and S. Hoque. 2012. Effects of naphthalene acetic acid on nutrient uptake by two varieties of rice (Oryza sativa L.). Dhaka Univ. J. Biol. Sci. 21(1): 9-15.

Akinrinde, E.K. 2006. Growth regulator and nitrogen fertilization effects on performance and nitrogen-use efficiency of tall and dwarf varieties of rice (Oryzae sativa L.). Biotechnology. 5(3): 268-276.

Akter, R. 2010. Effect of naphthalene acetic acid (NAA) on growth, physiological and biochemical responses and yield attributes of maize (Zea mays L. var. Pacific 383). M.S. Thesis. Department of Botany, University of Dhaka. pp. 81. 
Andrews, M., J. Leap, J.A. Raven and K. Lindsey. 2004. Can genetic manipulation of plant nitrogen assimilation enzymes result in increased crop yield and greater $\mathrm{N}$-use efficiency? An assessment. Annals Appd. Biol. 145(1): 25-40.

Baligar, V.C., N.K. Fageriaand, Z.L. He. 2001. Nutrient use efficiency in plants. Commun. Soil Sci. Plant Anal. 32: 921-950.

Cassman, K.G., A. Dobermann and D. Walters. 2002. Agroecosystems, nitrogen-use efficiency, and nitrogen management. AMBIO. 31: 132-140.

Chapin, F.S. III and I.F. Wardlaw. 1988. Effects of phosphorus deficiency on source-sink interaction between the flag leaf and developing grain in barley. J. Experimental Bot. 39: 165-177.

Chaturvedi, I. 2006. Effects of different nitrogen levels on growth, yield and nutrient uptake of wheat (Triticumaestivum L.). Internat. J. Agric. Sci. 2(2): 372-374.

Fertilizer Recommendation Guide 2012. Bangladesh Agricultural Research Council. Farmgate, Dhaka-1215. 274p.

Huq, S.M.I. and D. Alam. 2005. A handbook on analysis of soil, plant and water. Bangladesh Australia Centre for Environmental Research (BACER), University of Dhaka, Bangladesh. pp. 1-246.

Jahan, N. and A.A.M.G. Adam. 2014. Changes in biochemical component of rice following NAA application. J. Asiatic Soc. Bangladesh, Sci. 40(2): 173-178.

Jahan, N. and A.A.M.G. Adam. 2013. Growth and yield responses of BARI Gom-26 (TriticumaestivumL.) to naphthalene acetic acid. Dhaka Univ. J. Biol. Sci. 22(2): 119125.

Jahan, N. and A. A. M. G. Adam. 2011. Comparative growth analysis of two varieties of rice following naphthalene acetic acid application. J. Bangladesh Acad. Sci. 35(1): 113-120.

Jones, C., K. Olson-Rutz and C.P. Dinkins. 2009. Nutrient uptake timing by crops: to assist with fertilizer decisions. EB0191. Montna Stage University Extension, Bozeman, Montana. Pp 6.

Kumbhar, A.M., U.A. Buriro, F.C. Oad, Q.I. Chachar, M.B. Khmhar and G.H. Jamro. 2007. Yield and N-uptake of wheat (Triticumaestivum L.) under different fertility levels and crop sequence. Pak. J. Bot. 39(6): 2027-2034.

Laghari, G.M., F.C. Oad, S. Tunio, A.W. Gandahi, M.H. Siddiqui, A.W. Jagirani and S. M. Oad. 2010. Growth, yield and nutrient uptake of various wheat cultivars under different fertilizer regimes. Sarhad. J. Agric. 26(4): 489-497.

Nyborg, M., E.D. Solberg, R.C. Izaurralde, S.S. Malhi and M. Molina-Ayala. 1995. Influence of long term tillage, straw and fertilizer on barley yield, plant $\mathrm{N}$ uptake and soil-N balance. Soil and Tillage Res. 36: 165-174.

Patel, J.k. 1992. Effect of tricontanol and naphthalene acetic acid (NAA) on lint yield, fibre quality and nitrogen, phosphorus and potash uptake in cotton (Gossypium sp.). Indian J. Agron. 37: 332-337.

Purbey, S.K. and N.L. Sen. 2007. Effect of bioinoculates and bioregulators on yield and nutrient uptake by fenugreek (Trigonellafoenum-graecum L.). Indian J. Agric. Res. 41(2): 154156.

Rahman, R. and K. Venkatrama. 2006. Effect of foliar nutrition on NPK uptake, yield attributes and yield of greengram (Vigna radiate L.). Crop Res. 32(1): 21-23. 
Sing, H. and H.S. Gill. 1985. Effect of foliar spray of NAA on the growth and yield of late sown wheat and Barley. Indian J. Eco. 12: 267-272.

Smil, V. 1999. Nitrogen in crop production: an account of global flows. Global Biogeochem. Cycl.13: 647-662.

Steel, R.G.D., J.H. Torrie and D.A. Dickey. 1997. Principles and procedures of statistics. McGraw Hill Book Co. Inc. New York. Pp 666.

Tilman, D.,K.G.Cassman, P.A.Matson, R.Naylor and S.Polasky. 2002. Agricultural sustainability and intensive production practices. Nature. 418: 671-677.

(Revised copy received on 15-06-2016) 